\title{
Hydranencephaly: a rare cause of delayed developmental milestones
}

\author{
Azharuddin Mohammed Malik, ${ }_{1}^{1}$ Mehtab Ahmad, ${ }^{2}$ Afreen Khan, ${ }^{3}$ Ekram Ullah ${ }^{2}$
}

${ }^{1}$ Department of Medicine, Jawaharlal Nehru Medical College, Aligarh, Uttar Pradesh, India ${ }^{2}$ Department of Radiodiagnosis, Jawaharlal Nehru Medical College, Aligarh Muslim University, Aligarh, Uttar Pradesh, India ${ }^{3}$ Department of Medicine, Moti Lal Nehru Medical College, Allahabad, Uttar Pradesh, India

\section{Correspondence to} Dr Azharuddin Mohammed Malik,

malikazharuddin@gmail.com

\section{DESCRIPTION}

A 2-year-old female child presented with a history of delayed developmental milestones. According to her mother, the child was born out of a normal vaginal delivery and was apparently well after birth. However, by 6 months of age, the mother noticed that she was not interactive and did not recognise her. The child had failed to achieve head control by that time, but due to the ignorance and poverty of her family she did not get proper medical attention. At the time of presentation, she was still unable to recognise her mother, to speak or stand without support. She had hypertonia of all four limbs and plantar reflex was extensor bilaterally. Her fundus was normal and head appeared large with a circumference of $50 \mathrm{~cm}$ (>95th percentile for her age). Non-contrast CT of the child showed complete absence of bilateral cerebral hemispheres, replaced with fluid-filled spaces of cerebrospinal fluid density. Posterior fossa of the patient was normal with some soft tissue around the third ventricle representing malformed thalamic tissue. Intact falx cerebri was also seen in the interhemispheric plane, helping us to make a diagnosis of hydranencephaly (figure 1).

Hydranencephaly is an encephaloclastic anomaly characterised by the absence and replacement of the cerebral hemispheres with cerebrospinal fluid and necrotic debris, covered by leptomeninges. Hydranencephaly is the result of destruction and resorption of preformed solid cerebral tissue commencing before birth. ${ }^{1}$ The currently accepted pathogenic mechanism is an in utero bilateral internal carotid artery obstruction with evidence that the process might begin by as early as $8-12$ weeks of gestation. ${ }^{2}$ Parts of brain supplied by the posterior cerebral and vertebral arteries including the cerebellum, brain stem, thalamus and basal ganglia as well as
To cite: Malik AM, Ahmad M, Khan A, et al. BMJ Case Rep Published online: [please include Day Month Yearl doi:10.1136/ bcr-2013-009589

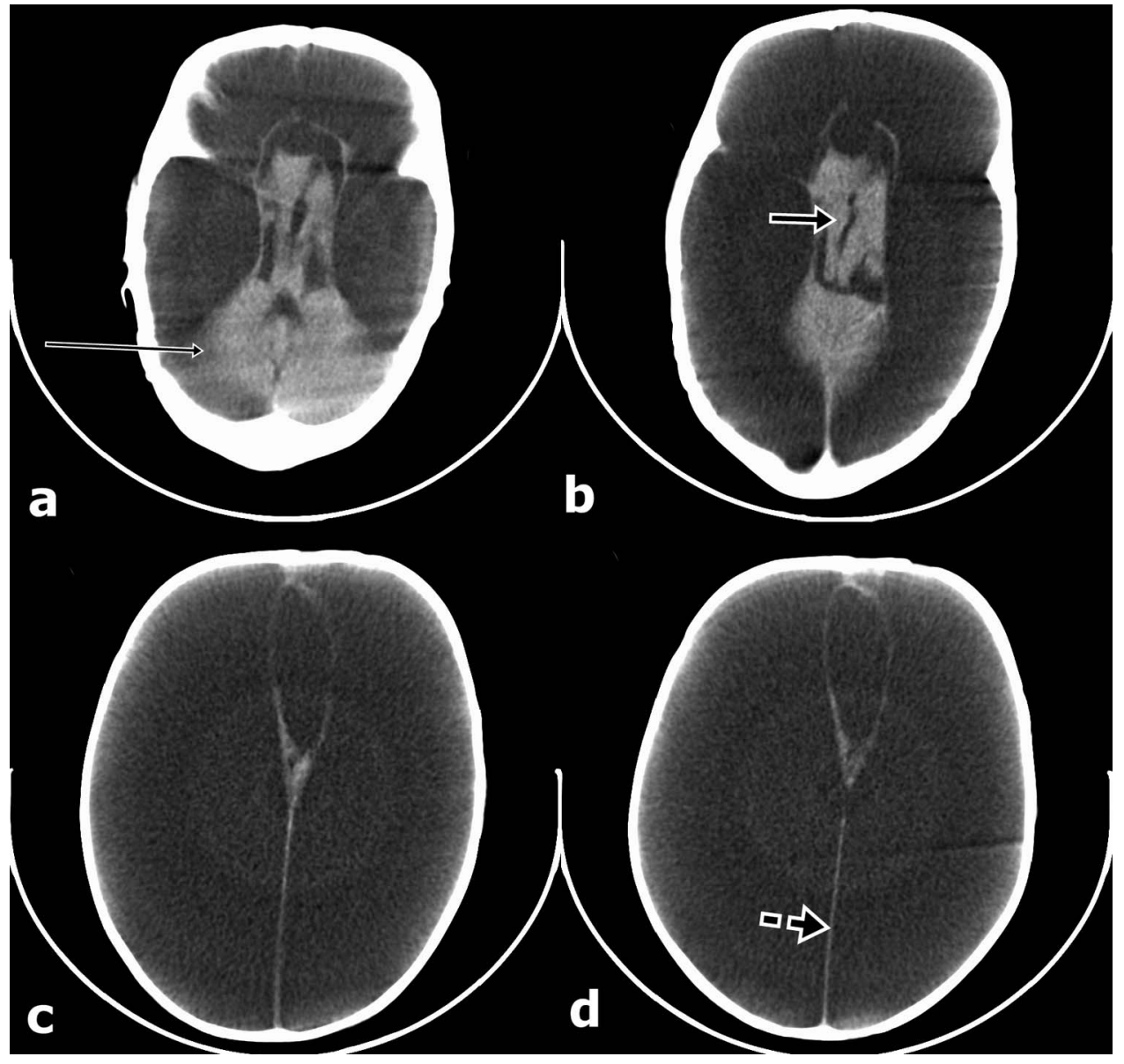

Figure 1 (A-D): Axial non-contrast CT images of 2-year-old baby taken at multiple levels showing bilateral cerebral hemispheres being replaced by the fluid containing spaces of cerobrospinal fluid density. Normal posterior fossa (thin arrow), intact falx (broken arrow) and malformed thalami (thick arrow) are seen. 
choroids plexus are usually preserved. Hydranencephaly can be differentiated from extreme hydrocephalus by the presence of a thin rim of a cortical mantle in the latter, whereas alobar holoprosencephaly is associated with the presence of falx and frequent coexisting midline facial abnormalities.

\section{Learning points}

- Hydranencephaly usually presents with severely delayed milesones during early childhood.

- Head size may be enlarged despite the absence of bilateral cerebral cortex.

- Non-contrast CT imaging is diagnostic.
Contributors AMM and AK were responsible for clinical workup and follow-up care of the patient. MA and EU were involved in diagnostic imaging. All authors contributed to the write-up and approval of the manuscript.

Competing interests None.

Patient consent Obtained.

Provenance and peer review Not commissioned; externally peer reviewed.

\section{REFERENCES}

1 Crome L, Sylvester PE. Hydranencephaly (Hydrencephaly). Arch Dis Child 1958;33:235-45.

2 Cecchetto G, Milanese L, Giordano R, et al. Looking at the missing brain: hydranencephaly case series and literature review. Pediatr Neurol 2013;48:152-8.

Copyright 2013 BMJ Publishing Group. All rights reserved. For permission to reuse any of this content visit http://group.bmj.com/group/rights-licensing/permissions.

BMJ Case Report Fellows may re-use this article for personal use and teaching without any further permission.

Become a Fellow of BMJ Case Reports today and you can:

- Submit as many cases as you like

- Enjoy fast sympathetic peer review and rapid publication of accepted articles

- Access all the published articles

- Re-use any of the published material for personal use and teaching without further permission

For information on Institutional Fellowships contact consortiasales@bmjgroup.com

Visit casereports.bmj.com for more articles like this and to become a Fellow 